\title{
REKONSTRUKSI SEJARAH SHALAT SEBAGAI LEMBAGA KEAGAMAAN ISLAM (Telaah kitab Tafsir Ibnu Katsir)
}

\author{
Oktari Kanus \\ UIN Imam Bonjol Padang \\ e-mail: oktarikanus@,gmail.com
}

\begin{abstract}
Abstrak
This research was conducted in order to reveal the details and details of the history of prayer history in the interpretation of Ibn Kathir. In this study, several important conclusions can be taken, First, prayer actually has been long before Islam came, as evidenced by the practices of prayer performed by Pagan around the Ka'bah in certain different ways and relationships with the way of Islamic prayer compilation comes. Second, from the interpretation data that the writer can convey the period of the stipulation of prayer in the interpretation of Ibn Kathir into two, namely the obligation prayer before Isra' and Mi 'raj, and obliation prayer by Isra' and Mi raj. To pray before Isra' and Mi raj, the Messenger of Allah had performed the evening prayer through Surat al-Muzzammil sentence 1 and prayed in the morning and evening with the anatomy of the raka'at prayer only two raka'at-dua raka' at, because of Isra 'and Mi raj as the beginning of the five-day prayer period, raka'at prayer still consists of two raka'at, the prayer provisions are fourteen raka'at fix the Prophet's compilation in Medina, by providing the two prayers raka at is given to those who is on the way (Safar) and prayer with four raka at is intended for the settled. Third, the night prayer required to complete the beginning of prophethood became the sunna of the compilation of Muslims already in Medina, due to the factor of seeing the enthusiasm of Muslims who performed the evening prayers so that they were burdensome.
\end{abstract}

Keyword: History, prayer, Ibnu Katsir

\section{Pendahuluan}

Shalat adalah ibadah suci yang sudah menjadi rutinitas setiap hari bagi umat Islam.Kenapa bisa demikian?,karena selain merupakan perintah Tuhan, shalat juga memiliki kedudukan yang amat penting dalam agama Islam.Ia menjadi fondasi bagi tegaknya agama Islam. ${ }^{1}$ Sejak

${ }^{1}$ Hal ini dijelaskan dalam hadis yang diriwayatkan dari Imam Bukhari bahwa shalat itu adalah fondasi dari agama Islam,(Telah menceritakan kepada kami Abdullah bin Musa diperintahkan pertama kali pada

dia berkata, telah mengabarkan kepada kami Hanzhalah bin Abu Sufyan dari 'Ikrimah bin Khalid dari Ibnu Umar berkata: Rasulullah shallallahu 'alaihi wasallam bersabda: "Islam dibangun diatas lima (landasan); persaksian tidak ada ilah selain Allah dan sesungguhnya Muhammad utusan Allah, mendirikan shalat, menunaikan zakat, haji dan puasa Ramadhan").Lihat Imam al-Hafiz Abu 'Abdillah Muhammad Ismâîlal-Bukhari, Shahîh al-Bukhâri, "Bab Islam Dibangun atas Lima Landasan," Hadis Nomer 8 (Amman: Bayt al-Afkar al-Dawliyyah, 1998M),13. 
peristiwa Isra' Mi'raj, shalat secara continue dipraktekkan umat Islam dari masa ke masa. Karena telah ditransmisikan tanpa putus dari generasi ke generasi, praktik ini menjadi suatu identitas bagi keagamaan umat Islam. Ia membentuk suatu persatuan dalam masyarakatIslam dan telah melembaga.

Dalam lanskap sejarah,shalatmelalui jalur-jalur yang tidak sederhana. Sudah menjadi pengetahuan umum, baik bagi umat Islam maupun non-muslim, yang meneliti tentang Islam, bahwa perintah shalat pertama kali diterima oleh Rasulullah pada peristiwa Isra dan Mi'raj. Rasullullah menerima perintah shalat dari Allah SWT secara langsung. Menurut sejarah, peristiwa Isra' dan Mi'raj merupakan suatu hiburan bagi Rasulullah.Hal ini disebabkan Ia baru ditinggalkan oleh orang-orang yang sangat Ia cintai yaitu istrinya Khadijah dan pamannya Abu Thalib. Tahun ini dikenal dengan tahun duka cita $\operatorname{Nabi}(\bar{A} m \quad a l-H u z n /$ tahun kesedihan) ${ }^{2}$.Jadi shalat merupakan buah tangan yang diwajibkan Tuhan kepada umat Islam yangdiperintahkan pertama kali ketika Rasulullah Isra Mi'raj.

Namun jika dilihat lebih jauh ke belakang, sebenarnya ibadah shalat telah dipraktekkanjauh sebelum peristiwa Isra Mi'raj.Hal ini tergambar pada ayat berikut, di mana ayat ini diturunkan pada masa awal kenabian.

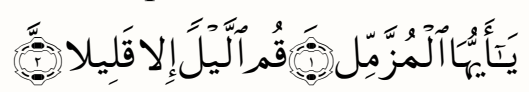

Artinya: Hai orang yang berselimut (Muhammad), bangunlah (untuk shalat) di malam hari, kecuali

${ }^{2}$ Abu Ahmadi, Mutiara Isra' Mi'raj, (Jakarta: Bumi Aksara, 2007), 27. sedikit (daripadanya).(Q.S. alMuzammil:1-2) 3

Ayat di atas menjelaskan tentang shalat malam, inilah shalat yang dilakukan sebelum peristiwa Isra' dan Mi raj oleh Nabi dan para sahabat. Abu Abdurrahman as-Sulami, al-Hasan, Ikrimah dan Qatadah dengan sanad yang shahih di dalam Fath alBaarimenjelaskan bahwa penetapan kewajiban shalat malam terjadi di Makkah, lebih dahulu daripada penetapan kewajiban shalat lima waktu di malam Isra' yang terjadi satu tahun sebelum Hijriah menurut pendapat yang shahih. ${ }^{4}$ Seiring dengan itu,Ali bin Abi Thalib mengabarkan bahwa Nabi Muhammad dan Siti Khadijah juga melakukan shalat berjamaah. Sementara ketika itu Ali bin Abi Thalib masih remaja. ${ }^{5}$

Ayat dalam surat al-Muzammil di atas, menurut Ibnu Katsir, merupakanperintah kepada Rasul-Nya untuk meninggalkan selimut yang menutupi dirinya di malam hari, lalu bangun untuk menunaikanibadah shalat kepada Tuhannya dengan melakukan qiyamullail. ${ }^{6} \mathrm{Ibnu}$ Abbas mengatakan

\footnotetext{
${ }^{3}$ Departemen Haji dan Waqaf Saudi Arabia, al-Qur'ān dan Terjemahannya, (Madinah al-Munawwarah: Percetakan alQur’ān Khadim al-Haramain al-Syarifain Raja Fadh, 1410 H), 574.

4 Ahmad ibn 'Ali Ibn Hajar AlAsqalaniy, Penjelasan Kitab Shahih alBukhari,terj. Gazirah Abdi Ummah (Jakarta: Pustaka Azzam, 2008), VI, 258.

${ }^{5}$ Peristiwa Isra Miraj terjadi ketika Ali berumur tidak lagi remaja.Lihat.. Muhammad Husain Haekal, Sejarah Hidup Muhammad, (Jakarta: Penerbit Litera antarNusa, 2013), 87 88.

6 Surat as-Sajadah ayat 16 juga menjelaskan hal yang demikian, Lihat AlHafizh 'Imaduddin Abu al-Fida' Ismail Ibnu Katsir, Tafsir al-Qur'ānal-Azhìm, (Beirut: Maktabah al-Nur al-'Ilmiyyah, 1992), V, 293.
} 
pada permulaan turunnya awal surat alMuzzammil para sahabat melakukan qiyamul lail yang durasinyaserupa denganqiyamul lailpada bulan Ramadhan. Dan jarak tenggang waktu antara awal surat al-Muzzammil sampai dengan terakhir ayatnya memakan waktu kurang lebih satu tahun. Mereka mengerjakan qiyamul lail selama satu tahun sehingga telapak kaki dan betis mereka bengkak, hingga turunlah ayat 20 dari surat tersebut, para sahabat merasa lega dengan ayat tersebut. Hal yang sama dikatakan oleh al-Hasan al-Basri dan As-Saddi di dalam keterangan itu. ${ }^{7}$

Di sisi lain,al-Qur’ānjuga menyinggung tentang praktek shalat yang dilakukan oleh kaum Pagan. Hal ini mengindikasikan bahwa praktik shalat sebenarnya sudah dilakukan bahkan jauh sebelum Isra' Mi'raj. Meskipun tata cara shalat yang dilakukan tidak serupa dengan apa yang dilakukan setelah shalat diperintahkan kepada Nabi. Allah berfirman dalam surat al-Anfal: 35:

Artinya:shalat mereka di sekitar baitullah itu, lain tidak hanyalah siulan dan tepukan tangan.(Q.S al-Anfal: 35$)^{8}$

Ayat ini dijelaskan oleh mufassir bahwa kaum Quraisy melakukan tawaf dalam keadaan telanjang, bersiul, dan tepuk tangan. Kata "shalatuhum" dalam ayat di atas artinya "doa-doa mereka"; mereka bersiul dan tepuk tangan sebagai ganti doa dan bacaan tasbih. ${ }^{9}$ Dalam tafsir Ibnu Katsir dan

\footnotetext{
${ }^{7}$ Ibid., 354

${ }^{8}$ Departemen Haji dan Waqaf Saudi Arabia, al-Qur`ān dan Terjemahannya, 181.

${ }^{9}$ Jawwad 'Ali, Sejarah Shalat (Asalusul, Bilangan dan Kedudukan Shalat dan Islam), terj. Irwan Masduki, (Tanggerang: Lentera Hati, 2010), 11.
}

tafsir ath-Thabari ayat tersebut artinya, "Tidak ada shalat dan ibadah bagi mereka, kecuali sekedar permainan." Versi lain mengatakan, "Shalat kaum Jahiliyah yang diyakini oleh mereka dapat menolak pengaruh-pengaruh buruk tak lain hanyalah shalat dengan cara bersiul dan bertepuk tangan. Kaum jahiliyah juga mengerjakan shalat untuk orang yang sudah meninggal dunia, misalnya dalam bentuk menangis dan menampakkan kesedihan atas meninggalnya orang tersebut dengan berdiri di atas kuburnya. ${ }^{10}$ Seperti itulah gambaran shalat yang dilakukan oleh orang-orang sebelum masa Nabi Muhammad yang sudah mempunyai tradisi ibadah shalat yang tertentu pula.

Adanya informasi dalam tafsir Ibnu Katsir ini menjadi sangat menarik, bagaimana sebenarnya shalat itu difardhukan sejak mula sampai mutawwatir kepada umat Islam seperti sekarang.Sudah menjadi sebuah institusi dalam agama ini.Sejarah shalat yang bermula dari diri Nabi Muhammad SAW sampai sekarang telah melalui waktu yang sangat panjang dan sudah menjadi identitas dari seorang muslim dengan shalatnya. Shalat itu sendiri sudah menjadi institusi dalam Islam sebagai pemersatu seluruh umat Islam, di manapun dan siapapun di dunia ini. Proses pelembagaan shalat yang terjadi dalam sejarahnya sangat kental dan mengikat bagi umat Islam, dan bahkan jika seseorang dengan sengaja meninggalkan atau mengingkari kewajiban shalat, maka dia termasuk

${ }^{10}$ Lebih jelas lihatKatsir, Tafsir alQur'ānal-Azhīm,IV, 293., dan Abi Ja`far Muhammad Ibnu Jarir al-Tabariy, Jami`alBayan an-Ta 'wil ay al-Qur 'ān, (Kairo: Dar alHadith, 2010), V, 812-813. 
orang-orang kafir dan telah keluar dari agama Islam, dan itu telah menjadi kesepakatan umat Islam. ${ }^{11}$

Penulis mengambil penafsiran dari Ibnu Katsir karena, di samping dia sebagai ahli tafsir, beliau juga piawai dalam bidang sejarah, terbukti dalam karyanya yang sangat monumental di dalam sejarah yaitu al-Bidayah wa alNihayah, tentu ini akan sangat menarik untuk dilihat, bagaimana kedua karyanya ini akan bersinergi di dalam penetapan shalat.

Dalam penelitian ini penulis menggunakan teori konstruksi sosialnya Peter L. Berger untuk melihat bagaimana proses pelembagaan shalat yang terjadi di dalam agama Islam sehingga menjadi institusi yang dikenal seperti saat sekarang ini.

\section{Asal Usul Shalat}

Shalat yang sudah dikenal saat sekarang tidak terjadi begitu saja, ada proses panjang yang mengawalinya, tidak turun secara spontan, akan tetapi turun secara bertahap. Setidaknya ada dua tahapan yang terjadi di dalam proses ini, yaitu tahapan pada masa umat Islam di Mekkah atau sebelum peristiwa Isra' dan Mìraj dan tahapansaat Isra' dan Mi raj terjadi dan setelahnya sampai umat Islam hijrah ke Madinah.Ada beberapa indikator shalat yang belum disempurnakan pada tahapan Mekkah disempurnakan pada tahapan Madinah, dan di Madinah-lah shalat diperintahkan secara sempurna kepada umat Islam.Hal ini sejalan dengan tabiat kenabian yang belum

11 Muhammad Ibnu Ali Ibnu Muhammad al-Shawkany, Nayl al-Awtar Syarh Muntaqa al-Akhbar bihi Ahadith Sayyid alAkhbar, (Kairo: Matbah Mustafa al-Babiy alHalabi, s.a), I, 369. sempurna dan tuntas, kecuali setelah di Madinah. ${ }^{12}$

Untuk membuktikan argumen tersebut penulis melakukan penelusuran di dalam al-Qur'ān terhadap ayat yang berkaitan dengan penetapan shalat pada tahapan sebelum Isra' dan Mi'raj dan tahapan sesudahnya atau indikasi yang mengarah kepada penetapan tersebut. Untuk menelusuri ayat-ayat yang berkaitan dengan kedua tahap tersebut penulis mengambil inisiatif dengan dua langkah, pertama dengan menggunakan kita al-Mu jam alMufahras li Alfāzh al-Qur'ān alKarīm ${ }^{13}$ karya al-Allamah al-Muhaqqiq Muhammad Fuad Abdul Baqi untuk melihat kata (fi'il atau isim) dari kata shalat dan perubahan katanya. Kedua, dengan memunculkan ayat-ayat secara langsung, ayat tersebut dicurigai terdapat indikasi penetapan shalat baik itu di dalam tahapan sebelum Isra' dan Mi'raj maupun tahapan sesudahnya dari berbagai sumber tafsir yang penulis baca.

Dari 107 ayat yang terdapat kata shalat di dalam al-Qur'ān dengan berbagai variasi makna dan kondisi, setelah penulis analisa dan filter dari beberapa ayat tersebut penulis memilih dan mengelompokkan ayat-ayat yang mengindikasikan kepada penetapan shalat pada kedua tahapan tersebut sesuai dengan informasi yang ada di dalam kitab Mu jam dan sumber tafsir.

\footnotetext{
${ }^{12}$ Jawwad 'Ali, Sejarah Shalat (Asalusul, Bilangan dan Kedudukan Shalat dan Islam), terj. Irwan Masduki, (Tanggerang: Lentera Hati, 2010), 30. Al-'Allamah al-Muhaqqiq Muhammad Fuad Abdul Baqi, al-Mu jam alMufahras li Alfāzh al-Qur'ān al-Karīm,(Mesir: Darut Hadits, $1364 \mathrm{H}$ )
} 
Kronologi pengfardhuan Shalat di dalam al-Qur'an dan rekonstruksinya di dalam tafsir Ibnu Katsir

Ketika melihat sejarah shalat, akan tergambar bagaimana dan seperti apa syariat itu bermula, serta apa saja hal-hal yang melatarbelakanginya. Kalau boleh dihubungkan dengan pengaruh faktor sosial kebudayaan, tentu ini akan bermuara kepada produk budaya, namun yang pasti shalat bukanlah produk budaya, karena perintah ini diwahyukan oleh Allah kepada Nabi Muhammad. Semua perintah itu autentik dari Tuhan sebagai penciptanya sehingga disebut dengan kalamullah. Namun, shalat bukanlah anti budaya, karena Allah menurunkan perintah ini dengan menggunakan pendekatan budaya, karena shalat sudah ada sebelum Islam datang, implikasinya shalat yang dibawa oleh Rasulullah akan berpengaruh secara praktek yang menggabungkan kedua bentuk teknik shalat dan menjadi satu sebagai wacana shalat baru yang berlandaskan ketauhidan.

Secara umum, Allah mewahyukan kalam-Nya kepada Nabi Muhammad sebagai pembawa perintah agama didasari oleh status sosialnya sebagai anggota suku Quraisy, termasuk perintah shalat. Sebuah suku yang menjadi acuan bagi suku-suku yang lainnya pada masa itu. Shalat dalam artian ketika perintah kefardhuannya belum turun, shalat telah terlebih dahulu dipraktikan oleh penduduk Mekkah umumnya pada waktu itu, ini sudah menjadi sebuah tradisi yang kuno di dalam sejarahnya. Islam datang dan mereproduksi rutinitas ini dengan melakukan perubahan-perubahan di dalamnya yang berporos kepada konsep tauhid dan monoteisme.

Jadi dengan konsep adopsi, adaptasi dan enkulturasi, al-Qur'ān berdialektika dengan budaya manusia. Tradisi keagamaan yang sudah dipraktikkan suku-suku Arab pada waktu itu adalah haji dan umrah, memuliakan hari jum at, sakralisasi bulan Ramadhan, shalat menyembah berhala di sekitar Ka'bah dan mengagungkan bulan-bulan haram. ${ }^{14}$ Tradisi-tradisi tersebut sudah menjadi ritual yang sudah melembaga dalam masyarakat Arab.

Sebelum melangkah lebih jauh terhadap argumen-argumen di atas, kembali kepada kalimat pembuka tulisan ini, akan dilihat bagaimana syariat ini bermula dalam perspektif Ibnu Katsir dalam tafsirnya dengan mengolah data dari penafsiran ayat yang berkaitan dengan kefardhuan shalat pada topik sebelumnya.Dalam penafsiran pada topik sebelumnya penulis telah membagi penafsiran dua periode perkembangan shalat, yaitu shalat sebelum Isra' dan Mi raj atau sebelum masa hijrah dan shalat setelah peristiwa tersebut atau setelah hijrah. Pada pembahasan ini akan diurai, dianalisa dan disusun secara kronologis dari kedua periode tersebut sehingga akan terlihat dari awal bermula syariat tersebut sampai dikenal umat Islam pada saat ini. Rekonstruksi shalat yang ditulis ini, penulis sadari tidak serinci dan sehistoris mungkin, dikarenakan data-data yang tidak secara spesifik penulis dapatkan dan adanya perbedaan pendapat para ulama dan sejarawan terkait informasi kefardhuan shalat tersebut, sehingga membuat sejarah

\footnotetext{
${ }^{14}$ Khalil Abdul Karīm, al-Judzūr al-
} Tarikhiyyah li al-Syariah al-Islamiyah, (Kairo: Dar Misra al-Mahrusah, 2004), 5-14. 
shalat menjadi kabur dan tidak bisa dipastikan secara akurat. Paling tidak dari data-data yang penulis dapatkan terkait rekonstruksi sejarah shalat di dalam tafsir Ibnu Katsir dan data pendukung lainnya, sudah dapat diklasifikasikan secara umum bagaimana perkembangan, perubahan dan penetapan kefardhuan shalat yang dari kedua periode tersebut.

\section{Kefardhuan Shalat Sebelum Isra' dan Mi raj}

a. Pengfardhuan Shalat Malam

Sejarah mencatat jauh sebelum Isra' dan Mi'raj bahkan sebelum Islam datang sudah ada praktik shalat yang dilakukan oleh penduduk Mekkah di sekitar Ka'bah, dengan tata cara dan ada istiadat tertentu. Akan tetapi dalam sub-bab ini penulis akan berangkat dari versi ketika Islam datang ke tanah Arab, yaitu ketika wahyu turun kepada Nabi Muhammad SAW. Melihat kronologi penurunan al-Qur'ān, wahyu yang turun di awal-awal kenabian yang mengindikasikan adanya perintah shalat adalah surat al-Muzzammil [73] ayat 1-2, "Hai orang yang berselimut (Muhammad), bangunlah (untuk shalat) di malam hari, kecuali sedikit (daripadanya)" berdasarkan tiga riwayat yang diambil, yaitu Ibnu Abbas, Umar Ibnu Muhammad Ibnu Abdul al-Kafi dan dari Ikrimah dan Husain Ibnu Abi al-Hasan, wahyu ini digolongkan kepada surat yang ketiga turun dari urutan kronologisnya. Dia turun sebelum surat al-Muddaṡsir dan sesudah surat al-Qalam. ${ }^{15}$

${ }^{15}$ Taufik Adnan Amal, Rekonstruksi Sejarah al-Qur`ān, (Jakarta: Divisi Muslim Demokratis, 2011), Ed. Digital, 102. Lihat juga Muhammad Hadi Mar'rifat, Sejarah alQur`ān, (Jakarta: Al-Huda, 2007), II, 81.
Di lain pihak dalam tafsir Ibnu Katsir agak sedikit berbeda dalam masalah urutan kronolgisnya, dia lebih mendahulukan surat al-Muddaṡsir sebelum surat al-Muzzammil setelah sebelumnya awal wahyu adalah surat al-Alaq ayat $1-5 .{ }^{16}$ Terlepas dari itu semua surat al-Muzzammil merupakan surat yang turun di masa awal kenabian, yaitu ketika Nabi Muhammad sudah menginjak umur 40 tahun, atau sekitar tahun 610 Masehi. ${ }^{17}$ Sudah jelas surat ini turun sebelum hijrah dan sebelum peristiwa Isra dan Mi raj.

Ayat ini turun memberikan perintah kepada Nabi Muhammad untuk melaksanakan shalat malam. Menurut Ibnu Katsir shalat yang diperintahkan di sini khusus hanya untuk pribadi Rasul ketika surat ini turun. ${ }^{18}$ Sedangkan riwayat dari Aisah $^{19}$ dapat penulis analisa bahwa

${ }^{16}$ Abi al-Fida' Isma'īl Ibnu Katsir, alBidayah wa al-Nihayah, (Beirut: Dar alMa`rifah, 2007), II, 21-22.

${ }^{17}$ Abi al-Fida' Isma'̄̄l Ibn Amar IbnKatsir al-Qarshiy al-Dimashqiy, Tafsir alQur 'ānal-Azhìm, (Riyad: Dar Tayyibah, 2007), V, 249.

${ }^{18}$ Ibid., 7.

19 Aisyah dari Abu Saiamah mengatakan, bahwa Aisyah menceritakan "dia pernah mempersiapkan tikar hamparan untuk tempat shalat Rasulullah di malam hari, para sahabat mengintipnya dan mereka berkerumun mendengarkannya, maka Nabi keluar seperti orang yang sedang marah, padahal beliau sayang kepada mereka. Beliau merasa khawatir jikaqiyamul lail difardhukan atas mereka, maka beliau bersabda, 'Beramalah semampu kalian.Sesungguhnya Allah tidak berpaling dari memberi pahala selama kalian beramal. Dan sebaik-baiknya amal adalah sesuatu yang kalian lakukan secara terus-menerus. Dan turunlah ayat: "Wahai orang yang berselimut, bangunlah dan dirikanlah shalat malam kecuali sedikit” (al-Muzzammil [73]: 1-2). 
penetapan shalat malam di tetapkan di Madinah, karena Rasul tidak menikahi Aisyah, kecuali setelah hijrah di Madinah, kemudian cerita tentang orang-orang yang berkumpul di sekitar rumah Rasulullah tidak menunjukkan itu terjadi di Mekkah, sebab umat Islam masik sedikit, akan tetapi sebaliknya perkumpulan itu terjadi di Madinah ketika umat Islam sudah banyak. Ibnu Katsir sendiri mengatakan bahwa riwayat tersebut lemah. Konteks hadis di atas memberikan pengertian bahwa surat ini seakan-akan diturunkan di Madinah, padahal kenyataannya tidaklah demikian. Sesungguhnya surat ini tidak lain adalah surat Makkiyah. ${ }^{20}$ Analisa penulis terhadap riwayat tersebut bahwa selama di Mekkah Nabi melakukan shalat malam sesuai dengan perintah yang ada di dalam ayat tersebut khusus bagi diri beliau sendiri. Dan pada saat di Madinah beliau masih melakukan shalat malam tersebut, akan tetapi para sahabat iri dan ingin melaksanakan shalat tersebut bersama beliau, lalu di dalam riwayat tersebut diturunkanlah ayat ini, artinya ayat ini bisa saja turun dua kali, pertama turun pada saal awal kenabian di Mekkah dan yang kedua turun pada saat Nabi berada di Madinah ketika umat Islam sudah banyak dan aman dari ancaman kaum Quraisy, kalau dilihat dari riwayat tersebut.

\section{b. Pengfardhuan Shalat Pada Waktu Pagi dan Sore Hari}

Setelah shalat malam diwajibkan kepada umat Islam, Selanjutnya shalat yang diwajibkan di dalam Islam adalah shalat pada waktu pagi dan sore hari,

Maka diwajibkanlah shalat malam kepada mereka.

${ }^{20}$ Ibnu Katsir, Tafsir al-Qur 'ànal-Azhìm, ini tergambar di dalam surat al-Alaq [96] 9-10, "Bagaimana pendapatmu tentang orang yang melarang, seorang hamba ketika dia mengerjakan shalat", Ibnu Katsir mengatakan bahwa ayat ini turun karena Abu Jahal, ia mengancam Nabi Muhammad SAW jika melaksanakan shalat di sisi Ka 'bah. ${ }^{21}$ Banyak kitab sejarah yang menceritakan tentang kisah ini, bahwa Nabi Muhammad telah melakukan shalat di Mekkah, tidah hanya beliau, umat Islam yang lain juga ikut melaksanakan shalat tersebut, ayat ini menurut mayoritas ulama adalah surah yang pertama kali turun dan terdapat petunjuk bahwa Rasulullah telah melaksanakan shalat pada masa awal kenabian. 22 Shafiyyurahman alMubarakfuri sendiri menambahkan bahwa peribadatan pertama yang diperintahkan Allah kepada Nabi Muhammad adalah shalat dua raka'at pada pagi dan dua raka'at pada sore hari. ${ }^{23}$ Riwayat lain untuk mendukung pendapat tersebut adalah sebelum Nabi melakukan shalat secara terangterangan di depan Ka'bah sebenarnya Rasulullah bersama Khadijah juga terlebih dahulu telah melakukannya secara sembunyi-sembunyi, akan tetapi seiring berjalannya waktu dan dengan turunnya surat al-Mudatsir perintah untuk melakukan dakwah secara

\footnotetext{
${ }^{21}$ Ibid., 437.

${ }^{22}$ Jawwad Ali,Tarikh ash-Shalat fi alIslam, terj. Irwan Masduki, (Tanggerang: Lentera Hati, 2013), II, 35. Lihat juga Martin Lings, Muhammad: His Life Based on the Earliest Source, (United Kingdom: The Islamic Texts Society, 1991), IV, 80.

23 Syaikh Shafiyyurahman alMubarakfuri, Sirah Nabi: Ringkasan Buku Sejarah Nabi SAW yang Fenomenal, al-Rahīq al Makthūm, (Bandung: Mizan, 2013), II, 45.
} 
terang-terangan, maka Nabi melakukan shalat di depan Ka 'bah. ${ }^{24}$

Untuk dalil yang memerintahkan shalat pada waktu pagi dan sore hari sebelum Isra' dan Mi'raj sebagaimana yang telah penulis deskripsikan pada bab sebelumnya, seperti surat Hūd [11]: 114 "Dan dirikanlah shalat itu pada kedua tepi siang (pagi dan petang) dan pada bagian permulaan daripada malam. Sesungguhnya perbuatanperbuatan yang baik itu menghapuskan (dosa) perbuatan-perbuatan buruk. Itulah peringatan bagi orang-orang yang ingat" dan surat surat Gāfir [40]: 44 "Maka bersabarlah kamu, karena sesungguhnya janji Allah itu benar, dan mohonlah ampunan untuk dosamu dan bertasbihlah seraya memuji Tuhanmu pada waktu petang dan pagi" setelah penulis analisa dari berbagai kitab sejarah al-Qur'ān yang menyusun kronologi surat Makkiyah, penulis dapatkan bahwa urutan dari surat Hūd dan surat Gāfir berada setelah urutan surat al-Isrā' yang di dalamnya tafsirannya mengandung perintah shalat lima waktu. ${ }^{25}$ Dan setelah penulis telusuri lebih lanjut ayat lain yang mengindikasikan perintah shalat pada waktu pagi dan sore hari tidak lebih semuanya turun pada periode Madinah, atau setelah Nabi hijrah dan tentu itu setelah peristiwa Isra' dan Mi raj terjadi. $^{26}$

\footnotetext{
${ }^{24}$ Ibnu Katsir, al-Bidayah wa alNihayah, III, 29.

${ }_{25}$ Athaillah, Sejarah al-Qur'ān (Verifikasi tentang Otensitas al-Qur'ān), (Yogyakarta: Pustaka Pelajar, 2010), I, 155, 158.Amal, Rekonstruksi Sejarah al-Qur'ān, 102. Mar`rifat, Sejarah al-Qur'ān, 82-83.

${ }^{26}$ Seperti surat al-Ahzāb [33]: 42, Dan dan bertasbihlah kepada-Nya di waktu pagi dan petang, dan surat al-Insān [76]: 25-26, Dan sebutlah nama Tuhanmu pada (waktu) pagi dan petang. 26- Dan pada sebagian dari
}

Pendapat penulis terhadap praktik waktu shalat yang dilakukan oleh Nabi Muhammad pada waktu pagi dan sore hari tersebut adalah adopsi dari prilaku ibadah dari kaum terdahulu, akan tetapi perintah untuk melakukan shalat sudah terdapat di dalam ayat terdahulu seperti surat alKausar yang turun lebih awal dari surat al-Isrā'."Maka dirikanlah shalat karena Tuhanmu dan berkorbanlah" (Q.S alKausar [108]: 2). Di tambah lagi dengan kabar tentang shalatnya Rasulullah yang diriwayatkan oleh ahli sejarah. Mereka menyebut bahwa Rasulullah keluar menuju Ka'bah pada pagi hari dan melaksanakan shalat Dhuhā. Shalat ini tidak diingkari oleh orang-orang Quraisy. ${ }^{27}$ Informasi ini, meski tidak menunjukkan praktik ritual shalat Dhuhā bagi kaum jahiliyah, namun memberi isyarat bahwa kaum Quraisy tahu tentang shalat Dhuhā, dan mungkin mereka juga mereka melaksanakannya, karena mereka tidak mengingkari shalatnya Rasulullah dan justru mereka membiarkannya.

Sebagai pertimbangan atas shalat yang dilakukan oleh Rasulullah, agama Yahudi juga mewajibkan umatnya mengerjakan shalat dalam sehari semalam, shalat pada hari Sabtu, saat tiba awal bulan, shalat setiap ada acara tertentu, dan shalat jenazah. Adapun shalat dalam sehari semalam yang diwajibkan oleh agama Yahudi adalah shalat pada tengah malam dan shalat Shubuh yang mereka beri nama dengan Syama'. Saat mengerjakan shalat Syama' ini orang-orang Yahudi membaca ayat-ayat tertentu yang ada dalam kitab Taurat. Syama' merupakan

malam, maka sujudlah kepada-Nya dan bertasbihlah kepada-Nya pada bagian yang panjang di malam hari.

${ }^{27}$ Jawaad Ali, Sejarah Shalat, 12. 
ritual ibadah yang dikerjakan sebelum tidur dan saat bangun dari tidur, mereka mempunyai keyakinan dengan mengerjakan shalat pada dua waktu di atas dapat menghindarkan diri dari sesuatu yang menyakitkan, menjauhkan dari kejelekan, ruh-ruh jahat,dan dapat memadamkan api neraka. $^{28}$

Selain dua shalat di atas agama Yahudi juga mengerjakan tiga shalat lain yang mereka beri nama dengan Tephillah, yang pertama shalat yang mereka sebut dengan TephillahHasyhar yaitu shalat yang dikerjakan pada waktu Shubuh,kedua shalat Ashār yang mereka sebut dengan TephillahHamnahah, dan ketiga TephillahHa'rabit yang mereka kerjakan pada waktu shalat Maghrib. Jika dijumlah, shalat yang dikerjakan oleh orang-orang Yahudi baik dari Syama' dan Tephillah maka jumlahnya ada lima kali shalat yang mereka kerjakan dalam sehari semalam.Selain shalat lima waktu di atas, mereka juga mengerjakan shalat pada hari Sabtu sedangkan orang-orang Nasrani mengerjakan pada hari Minggu. Ini sama halnya dengan orang Islam yang mengerjakan shalat pada hari Jumat.Adapun shalat yang dikerjakan oleh orang Yahudi pada waktu datangnya awal bulan ini, juga dikerjakan oleh orang-orang Majusi yang mereka sebut dengan nama shalat Antaremah. ${ }^{29}$ Dengan adanya informasi seperti ini, maka tidak heran kaum Quraisy membiarkan apa yang dilakukan oleh Rasulullah, dikarenakan ritual ibadah shalat dengan waktu tersebut juga sudah dilakukan oleh

\footnotetext{
${ }^{28}$ Abraham Cohen, Everyman's Talmud, (New York: Schocken,1995), 286, 299, 405.

${ }^{29}$ James Hastings, Dictionary of the Bible, (New York: Baker Books, 1994),444.
}

umat terdahulu.Dari bukti-bukti di atas sangat jelas menunjukkan bahwa Nabi Muhammad sudah mengerjakan shalat dihadapan semua manusia semenjak tahun pertama dari tahun kenabiannya.

\section{Kefardhuan Shalat Setelah Isra dan Mi raj \\ a. Kefardhuan Shalat Lima Waktu Pada Malam Isra` dan Mi raj}

Seiring berjalan turun wahyu, umat Islam yang masih terlalu dini dan penuh tekanan terhadap kaum Quraisy yang sangat tidak senang dengan agama yang dibawa oleh Rasulullah, sehingga perkembangan Islam hanya baru terfokus kepada tauhid dan ibadah kepada Allah, puncaknya ketika peristiwa Isra' dan Mi`raj yang menurut penafsiran mayoritas ulama terdapat perintah ibadah shalat lima waktu di dalamnya. Dari Anas bin Malik mengatakan bahwa Allah SWT pertama kali mewahyukan kepada Nabi Muhammad, yaitu perintah untuk umat Islam supaya mengerjakan shalat lima puluh kali dalam satu hari satu malam, lalu beliau turun dari perjumpaanya dengan Allah dan bertemu dengan Nabi Musa dan bertanya: "Hai Muhammad, apa yang diperintahkan Rabmmu kepadamu?" Nabi menjawab: "Dia menetapkan shalat lima puluh kali dalam satu hari satu malam" Nabi Musa berkata: "Sesungguhnya umatmu tidak akan sanggup melakukannya"dan Nabi Musa menyarankan Nabi Muhammad untuk kembali kepada Allah untuk meminta keringanan akan perintah tersebut. Dan Nabi-pun bertemu dengan Allah untuk memintak keringanan tersebut.Kemudian Allah menguranginya menjadi sepuluh shalat dalam satu hari satu malam. Lalu beliau kembali kepada Musa, dan Musa-pun masih menyarankan beliau 
untuk memintak keringanan kembali, akhirnya menjadi lima kali shalat. ${ }^{30}$

Ulamasepakat shalat lima waktu diwajibkan pada waktu malam Isra' Mi'raj. Namun mereka masih berselisih pendapat mengenai tragedi Isra' itu sendiri. Sebagian riwayat menyatakan Nabi Isra' pada bulan ke 15 dari terutusnya menjadi Rasulullah. Ada pula yang mengatakan Isra' terjadi tiga tahun sebelum hijrahnya Nabi saw ke Madinah. Ulama lain mengakatan Isra'nya Nabi saw terjadi satu tahun sebelum hijrah. Sebagian lagi berpandangan bahwa Nabi Isra' pada tahun kelima dari kenabian. ${ }^{31}$ Dan sebagian sejarawan muslim berpandangan malam Isra' terjadi pada tahun ke 11 dari kenabian dan Isra' tersebut setelah wafatnya Siti Khadijah. ${ }^{32}$ Dari sekian pendapat mengenai Isra' dan Mi'raj penulis lebih memilih pendapat yang terakhir, sebab mayoritas sejarawan menyatakan Siti Khadijah wafat pada tahun ke-10 dari kenabian dan itu sebelum Isra'. Apabila ada ulama yang berpendapat

\footnotetext{
${ }^{30}$ Ketika perintah shalat sudah sampai lima Nabi Musa masih menyarankan Nabi Muhammad untuk kembali menghadap agar diberi keringanan, akan tetapi Nabi Muhammad meneguhkan hatinya bahwa umatnya sanggup melakukannya, hal ini dikarenakan Nabi Musa juga memiliki umat ketika diperintahkan untuk beribadah dengan ketentuan waktu tersebut, namun mereka lemah untuk melaksanakannya dan akhirnya meninggalkannya, sedangkan umat Nabi Muhammad lebih lemah secara fisik, hati, pandangan dan penglihatan. Lebih jelas lihat Ibnu Katsir, Tafsir al-Azhim, V, 8-9. Lihat juga Ibnu Katsir, Bidayah wa al-Nihayah, II, 128.

${ }^{31}$ Ibnu Katsir, al-Bidayah wa al-

Nihayah, II, 116.

32 Ibnu Katsir, al-Bidayah wa alNihayah, II, 116. Lihat juga Abu Zakaria Yahya bin Syaraf an-Nawawi, Syarh anNawawi 'Ala Muslim, (Beirut: Dar Ihya atTurats al-'Arabi,1392 H.),II, 274.
}

sebelum Siti Khadijah wafat sudah menjalakan ritual shalat maka shalat yang dikerjakan oleh Siti Khadijah itu bukanlah shalat lima waktu, akan tetapi beliau shalat sebagaimana Rasul mengerjakan shalat sebelum diwajibkannya shalat lima waktu.

Setelah Rasulullah menerima perintah shalat dari Allah lalu beliau turun di Baitul Maqdis dan ikut turun bersamanya para Nabi. Dan ketika masuk waktu shalat, beliau mengerjakan shalat bersama mereka di sana. Ibnu Katsir berpendapat kemungkinan itu adalah shalat shubuh pada hari itu juga, dan beliau menjadi Imam para Nabi di sana. ${ }^{33}$ Bagi diri Nabi inilah shalat yang pertama kali dilakukan oleh beliau setelah perintah shalat ditetapkan, yaitu shalat shubuh, akan tetapi tidak bagi umatnya. ${ }^{34}$ Untuk menentukan shalat apa yang pertama kali dilakukan oleh umat Islam setelah peristiwa Isra' dan Mi raj secara umum sangat sulit dibuktikan, ini dikarenakan tidak adanya sumber yang menjelaskan tentang hal itu secara pasti.

Akan tetapi ada sebuah riwayat yang menyatakan dari Nafi' bin Jubair bin Math'am. Nafi berkata, "Ketika shalat diwajibkan kepada Rasulullah, ${ }^{35}$ Jibril mendatangi Rasul, kemudian shalat Zhuhūr pada waktu siang ketika matahari tergelincir condong ke arah Barat, shalat Ashār pada waktu bayang-bayang sebuah benda melebihi panjangnya benda itu sendiri, shalat

\footnotetext{
${ }^{33}$ Ibnu Katsir, Tafsir al-Azhìm, V, 9.

${ }^{34} I b i d$., Lihat JugaMuhammad Al-Amin bin Muhammad Al-Mukhtar Asy-Syinqithi, Tafsir Adhwā'ul Bayān fi Idhah al-Qur'ān bi Qur'ān, (Mesir-Kairo: Darul Kutub alIlmiyyah, 1972), III, 634.

${ }^{35}$ Asumsi penulis ini terjadi persis setelah Isra` dan Mi ’aj malamnya.
} 
Maghrib pada saat matahari terbenam, shalat Isyā pada waktu hilangnya cahaya merah di langit barat, shalat Shubuh ketika keluarnya fajar shadiq (yakni cahaya putih yang melintang di ufuk timur). Keesokan harinya, Rasul menjalankan shalat Zhuhūr ketika bayang-bayang benda menyamai panjang benda itu sendiri. Shalat Ashār ketika bayang-bayang benda dua kali lipat panjangnya benda itu sendiri. Shalat Maghrib ketika matahari terbenam. Shalat Isyā pada waktu masuk sepertiga malam. Dan shalat Shubuh pada pagi hari. ${ }^{36}$ Akan tetapi penulis tidak dapat menemukan data yang mengatakan kapan waktu pelaksanaan tersebut secara pasti di dalam riwayat tersebut.

Dari analisa di atas penulis berpendapat bahwa praktik shalat lima waktu dilakukan oleh umat Islam setelah Rasulullah benar-benar paham akan waktu-waktu yang telah diajarkan oleh Jibril, sehingga beliau baru bisa mengajarkannya kepada umat Islam secara keseluruhan. Secara kebiasaan mungkin butuh waktu satu atau dua hari Rasulullah untuk memahami waktu-waktu shalat tersebut sehingga baru bisa diajarkan kepada umat Islam. Artinya tidak dalam waktu lama setelah peristiwa Isra dan Mi'raj terjadi. Akan tetapi shalat apa yang pertama kali dilakukan oleh umat Islam setelah peristiwa Isra' dan Mi'raj sangat sulit untuk dibuktikkan.

${ }^{36}$ Ibnu Katsir, al-Bidayah wa alNihayah, II, 126. Ibnu Hisyam, as-Siroh anNabawiyah, I, 156. Waktu-waktu shalat tersebut dijelaskan di dalam surat al-Isra [17] ayat 78-79. Sebagaimana yang telah dijelaskan pada bab sebelumnya.

\section{b. Perubahan raka'at Shalat dari dua raka'at menjadi empat raka at (Shalat Safar)}

Shalat yang dilakukan oleh umat Islam pada waktu Isra' dan Mi'raj hanya terdiri dari dua raka`at, sama dengan halnya shalat yang dilakukan sebelum Isra' dan Mi'raj, yaitu shalat dua raka'at pagi dan sore hari dan itu adalah shalat yang diwajibkan pada masa hidupnya Khadijah. Inilah pendapat mayoritas pada ulama termasuk Ibnu Katsir sendiri. ${ }^{37}$ Shalat lima waktu yang perintahnya turun pada malam Isra' adalah shalat lima waktu yang sekarang ini dikerjakan umat Islam, namun dahulunya masingmasing hanya terdiri dari dua raka at. ${ }^{38}$

Sedangkan shalat yang dilakukan umat Islam sekarang dengan 4 raka'at terjadi perubahan ketika setelah hijrah, dengan berlandaskan dalil surat anNisā' [4] ayat 101, "Dan apabila kamu bepergian di muka bumi, maka tidaklah berdosa kamu mengqashar shalat, jika kamu takut diserang orang kafir. Sesungguhnya orang kafir itu adalah musuh yang nyata bagimu" Dan hadis Aisah diriwayatkan oleh Ibnu Khuzaimah, Ibnu Hibban dan alBaihaqi melalui jalur Syabi, dari Masruq dari 'Aisah, "Shalat dalam keadaan mukim dan safar difardhukan dua raka'at dua raka'at. Ketika Rasulullah datang ke Madinah dan keadaan telah stabil ditambahkan pada shalat mukim dua raka'at dua raka'at. Adapun shalat shubuh dibiarkan

37 Al-Halibiy al-Shafi'iy,Sirah alHalibiyah, I, 302. Ibnu Sayyid al-Nas, Ibnu Abdul Hadi, Min Uyūn al-Atsār fi Fanūn alMaghaziy wa al-Shamail wa al-Siyār, (Beirut: Dar al-Ma rifah, s.a), I, 140.

${ }^{38}$ Ibnu Katsir,Tafsir al-Azhìm, I, 515. Ibnu Katsir, Bidayah wa al-Nihayah, III, 128129. Ibnu Sayyid, Min Uyūn al-Atsā̄r, I, 140. 
sebagaimana adanya karena panjangnya bacaan, demikian pula dengan shalat maghrib karena ia merupakan witir shalat siang" kemudian setelah kewajiban empat raka'at telah tetap, maka diberi keringanan untuk shalat safar di dalam ayat di atas. $^{39}$

Ayat ini menggambarkan kebiasaan yang terjadi saat diturunkannya, karena sesungguhnya di permulaan masa Islam setelah hijrah, kebanyakan perjalanan mereka adalah penuh rasa takut. Bahkan mereka tidak keluar kecuali menuju perang umum atau dalam sutau pasukan khusus.Seluruh waktu di saat itu adalah gambaran perperangan terhadap Islam dan para penganutnya, inilah salah satu maksud pemahaman dari ayat ini “'Jika kamu takut diserang orang-orang kafir". ${ }^{40}$ Jadi dengan data-data di atas dapat disimpulkan bahwa, pada saat di Mekkah, shalat terdiri dari dua raka'at, tidak ada perbedaan antara seseorang yang berada di dalam rumah atau dalam perjalanan, akan tetapi ketika Nabi hijrah ke Madinah dan berdomisili di sana selama beberapa saat, ada yang bilang setelah selama satu bulan, tepatnya pada malam ke-12 Rabi’ats Tsanī, shalat di tambah dua

${ }^{39}$ Ibnu Katsir,Tafsir al-Azhìm, I, 515. Ibnu Katsir, Bidayah wa al-Niyahah, III, 245.Ahmad ibn 'Ali Ibn HajarAl-Asqalaniy, Penjelasan Kitab Shahih al-Bukhari, Judul Asli: Fath al-Baari Syarah Shohih al-Bukhāri, Penerjemah: Gazirah Abdi Ummah, (Jakarta: Pustaka Azzam, 2008), I, 19. Kesimpulan ini dikuatkan dari keterangan Ibnu Atsir dalam kitab Syarh Musnad, bahwasanya syariat meng-qashar shalat terjadi pada tahun keempat hijriah.

${ }^{40}$ Ibnu Katsir,Tafsir al-Azhīm, I, 516. raka at lagi bagi yang tinggal dirumah. Dan bagi yang dalam perjalanan atau musafir tetap seperti biasa dua raka'at. Turunnya perintah shalat bagi musafir ini terjadi pada awal tahun hijriah. ${ }^{41}$ Dan ketetapan tersebut telah dilakukan oleh umat Islam sampai saat sekarang ini.

\section{c. Penghapusan Kewajiban Shalat Malam Menjadi Sunat}

Selanjutnya terkait dengan perintah shalat malam yang jauh terlebih dahulu telah dilakukan oleh Rasulullah ketika awal-awal wahyu diturunkan masih senantiasa dilakukan oleh beliau bahkan sampai beliau di Madinah. Praktik shalat malam yang dilakukan oleh Rasulullah ini tercium oleh para sahabat, sesuai informasi hadis dari Siti Aisah terkait shalat malam Rasulullah di dalam surat alMuzzammil, riwayat dari Hakim Ibnu Aflah yang menanyakan tentang qiyamul lail Rasulullah kepada Siti Aisyah, lalu Siti Aisyah balik bertanya, bukankah engkau telah membaca firman-Nya: "Hai orang yang berselimut (Muhammad)"lalu Siti Aisyah menjelaskan bahwa Allah telah memfardhukan qiyamul lail melalui surat ini. Maka Rasulullah dan para sahabatnya melakukam qiyamul lail selama setahun penuh hingga telapak kaki mereka membengkak karena banyak mengerjakan shalat. Dan selama dua belas bulan, Allah menurunkan ayat terakhir sebagai keringanan buat mereka, sehingga

${ }^{41}$ Abu Ja far Muhammad bin Jarīr athThabarī, Tafsir ath-Thabarī al-Musamma Jami` al-Bayān fi Ta`wil al-Qur`ān, (Beirut: Dar al-Kutub 'Ilmiyyah, 1992), II, 400. Ibnu Sayyid al-Nas, Ibnu Abdul Hadi, Min Uyūn alAtsār fi Fanūn al-Maghaziy wa al-Shamail wa al-Siyār, (Beirut: Dar al-Ma`rifah, s.a), I, 195. 
jadilah qiyamul lail sebagai amal yang sunah setelah difardhukan, Sedangkan jalur lain riwayat Ibnu Jarir dari Sa id Ibnu Jubair mengatakan bahwa Nabi dan para sahabat melakukannya selamat sepuluh tahun. ${ }^{42}$

Sedikit berlawanan dengan informasi yang terdapat dalam kitab Bidayah wa Nihayah tersebut, di dalam kitab tafsirnya sendiri Ibnu Katsir mengatakan bahwa ayat terakhir dari ayat tersebut turun di Mekkah, artinya semua surat al-Muzzammil turun di Makkiyah, ini sejalan dengan pendapat dari Muhammad bin Ishaq Warraq yang dikenal dengan nama Ibnu Nadim dalam karyanya kitab al-Fihrist yang riwayatnya bersumber dari Muhammad Ibnu Nu'man bin Basyir, mengatakan bahwa ayat terakhir dari surat ini turun dalam perjalanan ke Madinah, atau setelah hijrah, artinya masih dalam periode Mekkah. ${ }^{43}$ Ibnu Katsir sendiri dalam tafsirnya menggolongkan ayat ini sebagai Makkiyah dikarenakan adanya perintah zakat di sana, "Dan dirikanlah shalat, tunaikanlah zakat", (Q.S al-Muzzammil [73]: 20), beliau menjelaskan bahwa ayat ini juga menjadi dalil bagi orang yang mengatakan bahwa kewajiban zakat diturunkan di Mekkah termasuk beliau sendiri, akan tetapi ukuran nishabnya belum dijelaskan kecuali di Madinah. Berarti kewajiban zakat sebenarnya sudah diperintahkan di Mekkah tetapi baru terealisasikan di Madinah ketika

\footnotetext{
${ }^{42}$ Ibnu Katsir,Tafsir al-Azhìm, 253.Lihat juga Jalaluddin as-Suyuthi, Lubābun Nuqūl fi Asbābin Nuzūl, Kairo: Darul Taqwa, t.t), I, 229.

${ }^{43} \mathrm{Abu}$ al-Faraj Muhammad Ibnu Ishaq Ibnu Muhammad Ibnu Ishaq, al-Fihrist, terj. Bayard Dodge, (Columbia University: New York \& London, 1970), I, 49
}

sudah ada takaran untuk ukuran zakat tersebut. $^{44}$

Ini artinya penghapusan shalat malam menjadi sunah bisa saja turun dua kali, pertama ketika Nabi dalam perjalanan dari Mekkah ke Madinah, kalau penulis lihat konteksnya seandainya ayat tersebut turun ketika dalam perjalanan Nabi dari Mekkah menuju Madinah, ini sejalan dengan logika karena saat itu Nabi dalam perjalanan jauh dan sedang dalam pengejaran kaum Quraisy yang memburunya, sehingga keringanan shalat malam diturunkan pada saat itu, seandainya beliau tetap melaksanakan shalat malam tentu ini akan memperlambat perjalanan beliau ketika dalam perjalanan sehingga bisa saja Rasulullah tertangkap oleh kaum Quraisy., Selain itu juga bisa memberikan waktu beristirahat bagi Rasulullah di malam hari setelah melewati panas siang hari yang terik. ${ }^{45}$

${ }^{44}$ Di sini nampak jelas perbedaan pendapat yang mengatakan ayat terkahir ini turun di Mekkah dan pendapat yang mengatakan di Madinah, sebagai penjelasan di atas orang yang mendasarkan bahwa ayat ini turun di Mekkah, maksudnya cuma perintahnya saja sedangkan realisasinya belum, sedangkan yang berpendapat di Madinah, karena realitanya zakat pertama kali dilakukan umat Islam ketika sudah berada di Madinah. Namun menurut pendapat mayoritas ulama, zakat mulai disyariatkan pada tahun ke-2 Hijriah di Madinah. Lebih jelas lihatIbnu Katsir, Tafsir al-Azhīm, V, 258 dan WahbahAlZuhayly, Zakat Kajian Berbagai Madzhab, (Bandung: PT Remaja Rosdakarya, 1995), 89.

${ }^{45}$ Tercatat di dalam sejarah beliau melakukan perjalanan hijrah bersama $\mathrm{Abu}$ Bakar lebih kurang selama 8 hari 7 malam, beliau berangkat dari Gua Tsur setelah menetap di sana selama tiga hari yaitu pada malam Senin tanggal 1 Rabi ul-Awwal tahun pertama Hijriah, atau pada tanggal 16 September tahun 622 Masehi. Dan sampai di Quba pada hari Senin pada tanggal 8 Rabi ul- 
Dan ketika Rasulullah berada di Madinah, beliau masih tetap melaksanakan shalat malam, karena bagi beliau itu hanya keringanan sementara selama perjalanan hijrah. Sesuai dengan cerita Aisah sebelumnya para sahabat mengetahui shalat malam yang dilakukan oleh Rasulullah dan ingin melakukannya bersama beliau, dan turunlah ayat pertama dari surat alMuzzammil sehingga shalat malam menjadi wajib ketika itu kepada umat Islam. Maka Rasulullah dan para sahabatnya melakukam qiyamul lail selama setahun penuh hingga telapak kaki mereka membengkak karena banyak mengerjakan shalat. Dan selama dua belas bulan, Allah menurunkan ayat terakhir sebagai keringanan buat mereka, sehingga jadilah qiyamul lail sebagai amal yang sunah setelah difardhukan. ${ }^{46}$

Sedangkan jalur lain riwayat Ibnu Jarir dari Sa`id Ibnu Jubair yang mengatakan bahwa Nabi dan para sahabat melakukannya selamat sepuluh tahun. Ini dapat dianalisa, bagi diri Rasulullah bisa dikatakan telah menjalankannya selama 10 tahun,

Awwal atau pada tanggal 23 September 622 Masehi. Lih. Syaikh Shafiyyur-Rahman alMubarakfury, Sirah Nabawiyah, terj. Kathur Suhardi, (Jakarta: Pustaka Azzam, 1997), 226, 232.

${ }^{46}$ Pendapat lain ada yang mengatakan bahwa kewajiban shalat malam telah di-nasakh dengan firman Allah, "Dan pada sebagian malam hari dirikanlah shalat tahajud sebagai suatu ibadah tambahan bagimu” (Q.S al-Isrā' [17]: 79). Lih. Abdullah Sholeh Mona alMazru', Fikih Shalat Imam al-Bukhāri, terj. Solihin dkk. (Jakarta Pustaka Azzam, 2011), 53. Pendapat lain menyebutkan, shalat malam tetap diwajibkan bagi Rasulullah tidak dinasakh. Lih. Ibnu Hajar al-Asqalani, Fathul alBari bi Syarhi Shah̄̄h al-Bukhāri,(Kaior: alMaktabah al-Salafiyah, t.t), II, 12. terhitung sejak syariat shalat malam ini diwajibkan, akan tetapi bagi diri sahabat, mungkin ada yang melaksanakan shalat malam tersebut sejak syariat itu diwajibkan, dan penulis asumsikan hanya sahabat yang pertama kali masuk Islam dan mendapatkan perintah serupa seperti yang dijalankan oleh Rasulullah dan diajarkan kepada para sahabat yang pertama masuk Islam.

Setelah turunnya dalil penghapusan shalat malam menjadi sunah setelah kewajibannya, hal-hal lain yang berkaitan dengan perubahan syariat shalat lainnya yang bersifat fundamental, seperti raka'at, waktu shalat, pemindahan kiblat dan wudhu yang akan dibahas setelah ini tidaklah ada, selain instrumen-instrumen lainnya sebagai penyempurna shalat seperti adab dalam shalat dan munculnya shalat-shalat sunat lainnya yang berkembang seiring meluasnya kekuasaan Islam, dan semakin kompleksnya masalah yang dialami oleh masyarakat Islam.

\section{d. Stabilisasi Shalat, Gerakan dan Bacaan}

Shalat yang sudah mapan dan hidup di dalam masyarakat Muslim dari waktu ke waktu terus mengalami perkembangan seiring semakin luasnya wilayah kekuasaan Islam secara tidak langsung membantu keberlangsungan keterjagaannya shalat. Shalat yang telah diajarkan oleh Rasulullah sejak awal mula diwajibkan telah menjadi aktifitas wajib yang dilakukan oleh umat Islam, sehingga ada keseragaman mereka dari segi gerakan, bacaan dan hal-hal lainnya.

Dari segi gerakan dan bacaan yang bersumber dari ciri shalatnya Rasulullah yang terkenal di dalam 
hadisnya "Shalatlah kalian sebagaimana melihat aku shalat" benarbenar matang telah dipahami oleh umat Islam ketika itu. Karena selain umat Islam yang hidup saat itu dan ikut shalat bersama Rasul tentu seandainya ada tata cara shalat yang kurang dipahami oleh sahabat dan umat Islam pada saat itu, mereka akan langsung menanyakannya kepada Rasulullah, sehingga tidak adalagi perbedaan di antara mereka.

Untuk generasi seterusnya setelah Rasulullah meninggal dan dokumentasi shalat yang hanya hidup di tengah masyarakat dengan realitas sosial yang ada atau boleh dikatakan dengan sunah shalat yang hidup di tengah masyarakat ketika masa sahabat. Akan tetapi ketika sudah memasuki masa setelahnya polemik politik Islam sudah mulai agak kacau, shalat yang sudah hidup di dalam kehidupan masyarakat tidak bisa diterima begitu saja tanpa adanya dalildalil hadis yang menjelaskan terhadap sikap shalat seseorang, terkait sikap shalat yang berbeda dari yang lainya, sehingga muncul hadis-hadis yang sepertinya bertentangan dengan tata cara shalat Nabi yang butuh akan penjelasan lebih lanjut atas sikat shalat Nabi yang berbeda-beda di dalam hadis. Analisa penulis dari sinilah terdapat perbedaan-perbedaan yang terjadi di dalam ibadah shalat dengan adanya hadis-hadis tersebut.

Akan tetapi perbedaan-perbedaan tersebut bukanlah hal-hal yang signifikan terhadap anatomi shalat secara keseluruhan. Perbedaan shalat hanya terjadi di dalam masalahmasalah furu iyah saja seperti cara mengangkat tangan ketika takbir, cara sujud, ruku' dan lain-lainnya. Secara prinsip shalat yang diakukan oleh umat
Islam dewasa ini bisa dikatakan sudah seragam dan tidak ada perbedaan yang mendasar sehingga merubah keutuhan shalat yang diajarkan oleh Rasullah.

\section{Pelembagaan Shalat Dalam Islam}

Semua kegiatan manusia selalu mengalami proses pembiasaan (habitualisasi) yang berulang-ulang, setiap perbuatan yang dilakukan diulang-ulang tersebut akhirnya akan menjadi sebuah pola yang kemudian bisa direproduksi dengan upaya sekecil mungkin dan dipahami oleh pelaku dari sebagai sebuah pola yang dimaksudkan itu. Pembiasaan selanjutnya berarti bahwa tindakan yang bersangkutan bisa dilakukan kembali di masa mendatang dengan cara yang sama dan dengan upaya yang sama dengan sebelumnya. Tindakan-tindakan yang dilakukan itu tetap mempertahankan sifatnya yang bermakna bagi seorang individu, meskipun makna-makna yang terlibat di dalamnya sudah tertanam sebagai hal-hal yang rutin dalam persediaan pengetahuannya yang umum (stock of knowledge), yang olehnya diterima begitu saja dan yang tersedia bagi proyek-proyek ke masa depan. $^{47}$

Begitu juga dengan shalat yang dikenal oleh umat Islam sekarang bermula dari sana. Kebiasaan yang dilakukan awalnya, akhirnya menjadi sebuah pola yang selalu dan terus menerus dilakukan sehingga masyakarat Islam sudah paham dengan

47 Peter L. Berger dan Thomas Luckmann, Tafsir Sosial Atas Kenyataan (Risalah tentang Sosiologi Pengetahuan), terj. Hasan Basri, (Jakarta: LP3ES, 1990), 72. Pembiasaan tersebut adalah proses dari pelembagaan (institutionalization), yaitu proses yang dilewati oleh suatu norma kemasyarakatan yang baru untuk menjadi bagian dari salah satu lembaga kemasyarakatn. 
pola tersebut sehingga bisa dilakukan di waktu lain dengan cara yang sama dan upaya yang sama besarnya dengan yang dilakukan dengan sebelumnya. Shalat yang dilakukan oleh umat Islam tersebut secara nilai tentu mempunyai nilai teologis yang bersumber dari Tuhan (sakral), ${ }^{48}$ melalui perintah dari Rasulullah dan dilakukan oleh umat Islam dengan tanpa pikir dan inilah hal yang mereka ketahui untuk bisa dilakukan terus menerus.

Proses-proses pembiasaan tadilah yang mendahului setiap pelembagaan. Menurut Petel L Berger, pelembagaan terjadi apabila ada suatu tipifikasi yang timbal balik dari tindakan-tindakan yang sudah terbiasa bagi berbagai tipe pelaku, dengan kata lain, tiap tipifikasi seperti itu merupakan satu lembaga. Jadi hal yang harus ditekankan di sini adalah sifat timbal-balik (resiprositas) dari tipifikasi-tipifikasi kelembagaan dan tipikalitas tidak hanya tindakan,

\footnotetext{
${ }^{48}$ Sifat sakral agama dalam kajian ini bukanlah yang berkaitan dengan ranah teologis akan tetapi wilayah sosiologis. Dalam kajian sosiologi sakralisasi agama yang dimaksud di sini berhubungan dengan ketentuan-ketentuan, norma-norma keagamaan, larangan-larangan yang memaksakan pemisahan radikal dari yang duniawi, atau segala sesuatu yang berada di atas segalanya, Durkheim menyebutkan lahirnya pengsakralan ini berhubungan erat dengan perkembangan masyarakat, tanpa adanya interaksi yang baik antara masyarakat dan norma itu, maka tak satupun kesakralan itu tetap utuh di dalam agama tersebut. Masyarakat menjadi tolak ukur perkembangan sebuah sistem sosial, begitu juga dengan agama, masyarakat itu sendirilah yang membentuk kesakralan tersebut, hal ini dijelaskan oleh Daniel L. Pals di dalam Seven of Religion pada bagian ke III tentang Kesakralan Masyarakat (Emile Durkheim), lebih jelas lihat Daniel L Pals, Tujuh Teori Agama Paling Komprehensif, terj. Inyiak Ridwan Muzir (Yogyakarta: IRCiSoD, 2012), 129.
}

melainkan juga dari pelaku-pelakunya dalam lembaga, dan setiap tipifikasi tindakan-tindakan yang sudah dijadikan kebiasaan dan membentuk lembaga merupakan milik bersama. ${ }^{49}$

Shalat tentu mempunyai tipifikasi, akan tetapi pedoman tipikal tersebut hanya bersumber kepada satu figur, yaitu Rasulullah sendiri, umat Islam keseluruhannya berusaha untuk meniru tipikal shalat yang dipraktikkan oleh Rasulullah berdasarkan hadishadis dan fakta sejarah yang menjelaskan tentang shalat Nabi, karena tipikal shalat yang dipedoman oleh umat Islam sekarang tidak bisa diciptakan secara seketika. Pelembagaan shalat mempunyai sejarah yang menghasilkan suatu lembaga itu, tidaklah mungkin untuk memahami suatu lembaga secara memadai, tanpa terlebih dahulu memahami proses historis bagaimana lembaga itu ada.

Berangkat dari sini, Peter L. Berger mencoba menawarkan sebuah teori bagaimana sebuah lembaga atau institusi itu terbentuk, dia mengatakan bahwa sebuah institusi masyarakat masyarakat tercipta dan dipertahankan atau diubah melalui tindakan dan interaksi manusia. Meskipun institusi sosial dan masyarakar terlihat nyata secara obyektif. Namun pada kenyataan semuanya dibangun dalam definisi subjektif melalui proses interaksi. Obyektivasi baru bisa terjadi melalui penegasan berulang-ulang yang diberikan oleh orang lain yang yang memiliki definisi subyektif yang sama. Pada tingkatan generalitas yang paling tinggi, manusia menciptakan dunia dalam makna simbolis yang

\footnotetext{
${ }^{49}$ Peter L. Berger dan Thomas Luckmann, Tafsir Sosial, 74.
} 
universal, yaitu pandangan hidupnya yang menyeluruh, yang memberi legitimasi dan mengatur bentu-bentuk sosial serta memberi makna pada berbagai bidang kehidupan. Singkat kata, Berger dan Luckmann ingin mengatakan terjadi dialektika antara individu menciptakan masyarakat dan masyarakat mencipta individu. Proses ini terjadi melalui ekstenalisasi, obyektivasi dan internalisasi. ${ }^{50}$ Lebih lanjut akan dibahas nanti

Secara ringkas teori tersebut mencoba mengatakan bahwa shalat yang sudah melembaga saat ini terjadi karena adanya interaksi antara pembawa perintah shalat Nabi Muhammad dan memberikan pengaruhnya kepada umat untuk ikut melaksanakannya serta berkembang dan bertransformasi secara continue sampai seperti yang dikenal sekarang, atau dengan kata lain Nabi Muhammad melakukan institutionalisasi shalat sebagai institusi dalam makna teologisantropologis terhadap umat Islam.

\section{a. Proses Peniruan Tata Cara Shalat Nabi (Eksternalisasi)}

Proses eksternalisasi merupakan salah satu dari tiga proses atau triad dialetika dalam kajian sosiologi pengetahuan. Proses ini diartikan sebagai suatu proses pencurahan keindividuan manusia secara terus menerus ke dalam dunia, baik dalam aktivitas fisis maupun mentalnya atau dapat dikatakan penerapan dari hasil proses internalisasi yang selama ini

\footnotetext{
${ }^{50}$ Burhan Bungin, Konstruksi Sosial Media Massa: Kekuatan Pengaruh Media Massa, Iklan Televisi dan Keputusan Konsumen serta Kritik Terhadap Peter L. Berger dan Thomas Luckmann, (Jakarta: Kencana, 2008), 14-15.
}

dilakukan atau yang akan dilakukan secara terus menerus ke dalam dunia, baik dalam aktivitas fisis maupun mentalnya. Termasuk penyesuaian diri dengan produk-produk sosial yang telah dikenal terlebih dahulu atau yang baru dikenalnya. Karena pada dasarnya sejak lahir individu akan mengenal dan berinterkasi dengan produk-produk sosial tersebut. Sedangkan produk sosial itu sendiri adalah segala sesuatu yang merupakan hasil sosialisasi dan interaksi di dalam masyarakat. ${ }^{51}$

Ekstenalisasi merupakan momen di mana seseorang melakukan adaptasi diri terhadap lingkungan sosialnya. Dunia sosial, kendati merupakan hasil dari aktivitas manusia, namun ia memposisikan dirinya sebagai suatu yang berunsur eksternal bagi manusia, sesuatu yang berada di luar diri manusia. Realitas dunia sosial yang mengejawantahkan, merupakan pengalaman hidup yang bisa dijadikan sebagai dasar seseorang untuk membentuk pengetahuan atau mengkonstruksi sesuatu.Realitas sosial, juga mengharuskan seseorang untuk memberikan responnya.Respon seseorang terhadap pranata-pranata sosial yang ada, bisa berupa penerimaan, penyesuaian maupun penolakan.bahasa dan tindakan merupakan sarana bagi seseorang untuk mengkonstruksi dunia sosiokulturalnya melalui momen ekternalisasi ini. Secara sederhana fase eksternalisasi dapat dipahami sebagai fase visualisasi atau verbalisasi pikiran dari dimensi batiniah ke dimensi lahiriah. Eksternalisasi merupakan

\footnotetext{
${ }^{51}$ Peter L. Berger, Langit Suci (Agama
} Sebagai Realitas Sosial), terj. Hartono (Jakarta: LP3ES, 1991), 5. 
proses pengeluaran gagasan dari dunia ide ke dunia nyata. ${ }^{52}$

Rasulullah sebagai pembawa agama Islam mengajarkan ritualshalat yang diterima ketika peristiwa Isra ' dan Mi raj sebagai penyelamat umat Islam di akhirat kelak, ${ }^{53}$ banyak ayat dan hadis yang menjelaskan tentang shalat yang akan mengantarkan manusia memasuki surga-Nya. Seperti surat alBaqarah [2] : 45-46, "Jadikanlah sabar dan shalat sebagai penolongmu. Dan sesungguhnya yang demikian itu sungguh berat kecuali bagi orang-orang yang khusyu', (yaitu) orang-orang yang meyakini bahwa mereka akan menemui Tuhannya dan bahwa mereka akan kembali kepada-Nya", dan hadis yang mengatakan bahwa shalat adalah kunci surga. 54 Ketika shalat dipandang sebagai sesuatu yang bisa mengantarkan manusia kepada keselamatan dan bisa memasukannya ke dalam surga,tentu umat Islam akan melaksanakan perintah tersebut tanpa ada pikir panjang, karena mereka yakin begitulah syariat yang harus dituruti untuk bisa mencapai keselamatan, yang akan memasukan mereka ke dalam

${ }^{52}$ Ibid.

${ }^{53}$ S.D. Goitein, Studies In Islamic History and Institutions, first edition, (Leiden: E.J. Brill, 1968), 79.

${ }^{54}$ Ibnu Abi Jumhur, Muhammad bin Zainuddin, 'Awâli al-Laâli al-Aziziyah fi alAhâdits al-Diniyah, Cet. Ke-1, (Kairo: Dar-alSyuhadah, 1405 H), I, 322. Muhammad Rei Syahri wa Hamkaran, Hukm Al-Nab Al-A 'zham $S A W$, Cet. Ke-1, (Mesir: Dar-al-Hadits, 1429 H), V, 285. Wahbat bin Mustafa Zukhaili, alTafsir al-Munir fi al- 'Aqidat wa al-Syari'ah wa al-Manhaj, Cet. Ke-2, (Beirut: Dar-al-Fikr alMa'ashir, 1418 H), VI, 102. Jalal al-Din Suyuthi, al-Durr al-Mantsur fi Tafsir alMa'tsur, (Kairo: Nasyr Kitabkhane Ayatullah

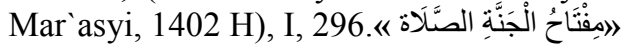

surga-Nya. Setiap perintah yang disampaikan oleh Rasulullah akan senantiasa diikuti oleh umat Islam, semua yang datang dari beliau akan mereka terima sehingga akan ada tatanan dunia sosio-kultural yang baru, di mana shalat dimaknai sesuatu yang akan memberikan kebahagiaan kepada mereka.Di sinilah momen eksternalisasi dari pelaksanaan tradisi shalat tersebut dalam keseharian umat Islam. Ini agak berbeda dengan sosiologi pengetahuan manusia secara umum, karena Rasulullah sebagai fitur yang membawa perubahan tersebut sebagai the power of God, sehingga individu yang lain tidak bisa melakukan penolakan terhadapnya, ini bukan berarti Islam datang mengabaikan konstruksi sosial yang ada, akan tetapi perintah tersebut berdialektika dengan adat-budaya setempat sehingga tidak terjadi perang argumen dengan kebiasaan yang ada, di sinilah peran nyata dari Islam berkembang di Arab dengan pendekatan budaya setempat atau istilah lain disebut dengan enkulturasi.

Islam datang dengan membawa perintah shalat, di mana shalat jauh terlebih dahulu sudah dikenal dalam lingkungan masyarakat disekitarnya. Shalat yang dibawa oleh Islam mencoba berdialektika dengan adat budaya setempat, seperti menambahkan gerakan ruku' dan sujud, adanya raka at dan waktu-waktu yang ditentukan, sehingga lebih terarah dan teratur. Seperti contoh orang Arab sebelum pra Islam menolak ruku' dan sujud, karena menurut mereka kedua gerakan tesebut dinilai sebagai simbol kerendahan, kehinaan dan kekotoran, mereka paling anti dengan sujud, karena mengangkat pantat ke paling adalah gerakan yang dinilai 
merendahkan harga diri. ${ }^{55}$ Islam datang merubah nilai tersebut dengan konsep tauhid yang mengajarkan bahwa segala sesuatu di hadapan Allah segalanya rendah.

Secara praktik, Rasulullah mengajarkan tata cara shalat kepada para sahabat di dalam banyak hadis, salah satu hadis yang terkenal adalah "shalatlah sebagaimana kalian melihat aku shalat" ${ }^{56}$, setiap gerakan, sifat shalat dan berbagai macam kebiasaan Nabi di dalam shalatnya ditiru dan dipraktikkan oleh para sahabat sebagai pembawa perintah shalat dari Allah. Setelah setiap sifat shalat Nabi dipahami dan dilakukan berulang-ulang oleh para sahabat, selanjutnya institusi shalat akan memasuki proses pencarian identitas shalat yang mempunyai standarisasi bagi para sahabat ketika itu, atau istilah lainnya obyektivasi.

\section{b. Standarisasi Praktik Shalat Pada Masa Rasulullah (Obyektivasi)}

Selanjutnya adalah proses obyektivasi. Proses objektivasi adalah fase mengkristalkan ke dalam pikiran tentang suatu objek, atau segala bentuk eksternalisasi yang telah dilakukan dilihat kembali pada kenyataan di lingkungan secara objektif. Jadi dalam hal ini bisa terjadi pemaknaan baru ataupun pemaknaan tambahan. Proses objektivasi merupakan momen interaksi antara dua realiatas yang terpisah satu sama lain, manusia di satu sisi dan realitas sosio-kultural di sisi lain. Kedua entitas ini seolah terpisah, kemudian membentuk jaringan interaksi intersubyektif.Fase ini

99.

${ }^{55}$ Ath-Thabari, Tafsir ath-Thabari, III,

\footnotetext{
${ }^{56}$ Shahīh al-Bukhāri, Hadis Nomer
} 6705. Sunan ad-Dārimī, Hadis Nomer 1225. merupakan hasil dari kenyataan eksternalisasi yang kemudian mengejawantahkan sebagai suatu kenyataan objektif yang sui generis, yang berciri khas. Pada fase ini juga ada proses pembedaan antara dua realitas sosial, yaitu realitas diri individu dan realitas sosial yang lain berada di luarnya, sehingga realitas sosial itu menjadi sesuatu yang objektif. Dalam proses konstruksi sosial, proses ini disebut sebagai interaksi sosial yang dibangun secara bersama. Pelembagaan akan terjadi manakala terjadi kesepahaman intersubjektif atau hubungan subjeksubjek yang berkaitan dalam kehidupan sosial tersebut. ${ }^{57}$

Di dalam konstruksi sosial momen objektivasi inilah terdapat realitas sosial yang menjadi pembeda dari realitas sosial lainnya. Objektivasi ini terjadi karena adanya proses eksternalinasasi yang mendahuluinya, tidak lepas begitu saja langsung menuju momen ini, karena setiap objektivasi butuh akan eksternalisasi terlebih dahulu. Ketika dalam proses sosial eksternalisasi ini semua ciri-ciri dan simbol dikenal oleh masyarakat umum di kebanyakan. ${ }^{58}$

Ketika shalat yangdiajarkan Rasulullah dan dipahami secara umum oleh para sahabat dengan makna

57 Nur Syam, Islam Pesisir, (Yogyakarta: Lkis Pelangi Aksara, 2005),44.

${ }^{58}$ Hal ini dijelaskan Peter L. Berger dalam karyanya Study of Releigion yang disusun oleh Linda Woodhead, Paul Heelas dan David Martin. Pada bagian ke II, Religion, Sprituality and The Discontents of Modernity. Lebih jelas lihat Peter L. Berger and The Study of Releigion, Edited by Linda Woodhead with Paul Heelas and David Martin, (London: Routledge, 2001), 5. 
keselamatan, tentu ada realita lain yang berada di realitas sosial umat Islam ketika perintah itu datang. Ketika seorangindividu berinteraksi dengan individu lain tentang makna shalat yang dikerjakan seperti para sahabat berinteraksi dengan para sahabat lain tentang shalat yang dia lakukan, tentang makna shalat yang mereka pahami, ketika yang mereka pahami tersebut sama, di sinilah proses obyektivasi tadi bekerja. Mereka secara tidak langsung bersepakat bersama dan akan terus melakukan seperti apa makna shalat yang mereka pahami masing-masing. Istilah lain dari realitas sosial lain yang seragam dengan eksternalisasi dari individu adalah faktasitas objektif, makna shalat yang dipahami oleh seorang individu sudah menjadi suatu hal yang hidup dan mengendap dalam masyarakat. akan tetapi sebenarnya ada hal yang sangat mendasar ketika umat Islam secara umum ketika memahami makna shalat ketika waktu itu, karena pribadi dan intelegensi seseorang yang berbedabeda, sehingga berkemungkinan akan menghasilkan pemaknaan yang berbeda, sehingga secara furu'iyyah terdapat perbedaan-perbedaan di dalam shalat, akan tetapi di sini penulis menggeneralisir semuanya itu kepada satu makna saja dengan berdasarkan alQur`an dan hadis.

Dari sinilah proses pelembagaan shalat tersebut mulai terbangun, ketika, ketika ada interaksi-interaksi yang terjadi antara individu sahabat dengan sahabat yang lain, antara Rasulullah sebagai pembawa perintah shalat dengan seluruh umat Islam ketika itu, dengan begitu, terdapat banyak kesepahaman yang intersubjektif sesama mereka, yang akhirnya melanggengkan pratik shalat tersebut sampai saat sekarang ini.

Selain makna shalat yang dipahami oleh para sahabat, ada faktor penentu lain yang membuat keseragaman shalat tetap terjaga sampai sekarang, yaitu adanya kesamaan tata cara shalat yang dilakukan oleh para sahabat yang bersumber dari Rasulullah. Ketika tata cara shalat sudah diajarkan kepada para sahabat, selanjutnya mereka secara tidak langsung akan megeneralisasikan setiap sifat shalat Nabi tersebut di dalam kehidupan sehari, seperti bagaimana cara Rasulullah ruku', sujud, berdiri, takbir dan gerakangerakan lainnya yang termasuk di dalam anatomi shalat yang diketahui umat Islam saat sekarang ini. Akhirnya proses mengenerasasikan setiap sifat shalat Nabi tersebut akan menjadi sebuah identitas shalat yang diakui secara umum dan hidup di tengahtengah kebiasaan shalat umat Islam di masa itu.

\section{c. Pelembagaan Shalat yang Continue (Internalisasi)}

Internalisasi adalah individuindividu sebagai kenyataan subyektif menafsirkan realitas obyektif, atau peresapan kembali realitas sosial oleh manusia dan mentransformasikannya sekali lagi dari struktur-struktur dunia obyektif ke dalam struktur-struktur dunia subyektif. Pada momen ini, individu akan menyerap segala hal yang bersifat obyektif dan kemudian akan dimanifestasikan secara subyektif. Internalisasi ini berlangsung seumur hidup seorang individu dengan melakukan sosialisasi. Pada proses ini, setiap individu berbeda-beda dalam dimensi penyerapan. Ada yang lebih menyerap aspek eksternnya, ada juga 
yang lebih menyerap bagian internnya. Selain itu proses internalisasi ini dapat diperoleh individu melalui proses sosialisasi primer dan sekunder. ${ }^{59}$

Sosialisasi primer merupakan sosialisasi awal yang dialami individu di masa kecil, di saat manusia mulai diperkenalkan dengan dunia sosial pada individu. Sosialisasi sekunder dialami individu pada usia dewasa dan memasuki dunia public, dunia pekerjaan dalam lingkungan yang lebih luas lagi. Sosialisasi primer biasanya sosialisasi yang paling berpengaruh bagi individu, bahwa semua struktur dasar dari proses sosialisasi sekunder harus mempunyai kemiripan dengan struktur dasar sosialisasi primer. ${ }^{60}$

Shalat yang sudah dipahami dalam realitas sosial sahabat setelah mengalami proses obyektivasi, umat Islam akan kembali memahami makna yang ada di dalam realitas sosial shalat ketika itu dan akan menstransformasikan sekali lagi ke dalam dirinya. Mereka akan memahami bagaimana realitas shalat yang terjadi dan akan dimanifestasikan secara individu di dalam kesehariannya. Aktivitas ini akan berlangsung seumur hidup sahabat tidak akan berubah, kecuali ada aturan baru yang datang dari Rasulullah sebagai pembawa perintah shalat. Para sahabat secara tidak langsung akan melakukan sosialisasi terhadap shalat yang mereka pahami secara individu.

Sosialisasi yang pertama kali mereka sampaikan adalah kepada anakanak mereka, tentang bagaimana pemahaman shalat yang sudah dipahami di dalam realitas sosial yang

\footnotetext{
${ }^{59}$ Peter L. Berger, Langit Suci, 20-24.

${ }^{60}$ Peter L. Berger dan Thomas

Luckmann, Tafsir Sosial,188.
}

sudah terjadi ketika itu, karena di sanalah semua konstruk sosial bermula yang akan tumbuh besar dan ikut dalam kontsruksi sosial di masa dia akan tumbuh dewasa. Pemahaman shalat yang didapatkan dari ketika kecil akan selalu mereka manifestasikan sampai mereka dewasa, ketika memasuki masa dewasa, di mana dia akan bergabung dengan realitas sosial shalat yang ada si anak akan cenderung memahami ajaran shalat yang diajarkan ketika dia kecil, karena masa inilah yang sangat berpengaruh di dalam perkembang dirinya.

$$
\text { Orang-orang }
$$

mengajarkannya tentang shalat dan maknanya di waktu kecil akan menjadi peranan bagi dirinya ketika mengambil sebuah sikap terhadap realitas shalat yang terjadi ketika dia dewasa, makna shalat dan gerakan shalat yang dipahaminya ketika kecil secara tidak langsung akan dinternalisasikan ke dalam dirinya. Dalam berhadapan dengan realitas shalat yang di dunia barunya si anak akan mendapatkan respon terhadap prilaku shalat yang di dapatkan ketika dia kecil, akumulasi dari respon tersebut akan digeneralisasikan ke dalam dirinya, sehingga akan membentuk indentitas shalat individu di dalam dirinya. Indentitas inilah yang nantinya akan membentuk konstruksi sosial shalat dan akan berdialektika dengan masyarakat shalat di sekitarnya.

Indentitas shalat ini nanti akan dibentuk oleh proses-proses sosial, apakah identitas shalat yang dia lakukan dipelihara, dimodifikasi, atau malahan dibentuk ulang oleh hubungan-hubungan interaksi sosial lainnya, karena indentitas shalat tersebut timbul karena fenomena dari dialektika antara individu dengan 
masyarakat secara umum, dan pada akhirnya identitas shalat individu tadi akan kembali kepada tahapan internalisasi dan begitu seterusnya sampai akhir zaman, bisa jadi konstruk shalat yang dibentuk berubah dari segi gerakan, nilai, dan esensi shalat tersebut tergantung realitas sosial apa dan bagaimana yang mempengaruhi perkembangannya.

Berdasarkan ketiga paparan proses dialektika sosial di atas, maka dapat diambil benang merahnya, bagi penulis sendiri yang ikut terlibat di dalam konstruk sosial shalat sebenarnya yang juga memahami shalat dan gerakannya, ketika shalat yang diperintahkan oleh Allah melalui perantara Rasulullah yang mengajarkan shalat itu adalah penolong umat Islam nanti di akhirat, sebagaimana yang telah dijelaskan di dalam bab pendahuluan, nilai inilah yang masih melekat pada diri penulis, di mana penulis yakini juga, nilai ini jugalah yang dipahami oleh umat Islam pada hari ini, sejak shalat tersebut disyariatkan sampai sekarang, sehingga umat Islam ketika itu bersama-sama mendirikan shalat, menjadikannya social-institution sampai sekarang. Terlepas dari perbedaan bagian anatomi shalat yang diperselisihkan oleh umat Islam, seperti cara memposisikan tangan ketika ruku', sujud, mengangkat tangan, bacaan iftitah yang sangat rentan akan perbedaan dan lain segala macam tersebut, ini terpengaruh dari si pengajar pertama tentang shalat tersebut di dalam dirinya sebagai penentu dalam realitas sosial di masanya. Nilai itu tadilah yang membentuk institusi shalat di masa sekarang.

\section{Kesimpulan}

Sebelum

Islam datang masyarakat Arab sudah terlebih dahulu mengenal shalat, terbukti dengan ritualritual ibadah yang dilakukan oleh masyarakat Arab di sekitar Ka'bah. Ketika Islam datang, praktik shalat yang sudah berjalan tersebut dicoba untuk dimodifikasi oleh Rasulullah dengan berlandaskan tauhid.

Sebelum peristiwa Isra' dan Mi'raj yang dikenal sebagai awal pensyariatan shalat, umat Islam terlebih dahulu sudah melakukan praktik shalat. Sejarah mencatat bahwa Rasulullah sudah melakukan shalat malam qiyamul-lail ketika berada di Mekkah, sebagaimana penafsiran Ibnu Katsir tentang surat al-Muzzammil [78] ayat 1-2. Selain itu, tidak hanya shalat malam, Rasulullah juga melakukan rutinitasnya di pagi hari untuk melaksanakan shalat di depan Ka'bah sebelum peristiwa Isra' dan Mi'raj terjadi, dan bahkan sejarah juga memaparkan Khadijah juga pernah melakukan shalat berjama`ah bersama Rasulullah, sebagaimana diketahui bahwa Khadijah wafat sebelum peristiwa Isra` dan Mi`raj terjadi.

Setelah peristiwa Isra` dan Mi'raj terjadi sebagai awal pensyariatan shalat lima waktu dikukuhkan, shalat yang dilakukan oleh umat Islam setelah peristiwa itu hanya terdiri dari dua rak'at saja, setelah hijrah ke Madinah dan sudah menetap di sana, shalat ditambah dua raka'at bagi yang menetap dan dua raka'at bagi yang melakukan perjalanan. Ini sejalan dengan tradisi orang Arab yang senantiasa melakukan perjalan sehingga diberi keringanan dikurangi jumlah raka`at shalat menjadi dua 
raka'at. Shalat berkembang sesuai dengan situasi dan kondisi masyarakat Arab, sehingga tidak menjadi sebuah kesulitan bagi masyarakat Arab untuk menerima perintah shalat tersebut. Waktu shalat diajarkan oleh Jibril kepada Rasulullah setelah peristiwa Isra dan Mi raj di siang harinya, sehingga shalat yang lima waktu tersebut bisa segera dilaksanakan oleh umat Islam.

Shalat yang sudah menjadi lembaga Islam saat ini, di dasari dari pemahaman yang sama terhadap pertama kali shalat tersebut dijadikan syariat. Pembentukan pengetahuan tentang shalat yang kemudian menjadi sebuah pemahaman ini melewati berbagai proses dan tahapan, yang mana proses ini dalam teori sosiologi pengetahuan Peter L. Berger disebut dengan proses eksternalisasi, berawal dari pengetahuan yang sangat mendasar "bahwa shalat tersebut secara konsep dan praktiknya merupakan sebuah kewajiban yang akan menyelamatkan manusia ketika diakhirat nanti", Pengetahuan ini diperoleh dari realitas sosial terdekat yaitu keluarga sendiri, terus berkembang ke lingkungan sosial, pada proses inilah mereka mulai mendapat pengetahuan yang lebih luas tentang shalat yang mereka pahami. Bahkan si anak tidak tertutup kemungkinan mereka bertemu dengan dalil-dali yang mengharuskan shalat. Momen bertemunya kedua realitas sosial ini disebut dengan obyektivasi. Pemahaman mereka terhadap dalil-dalil ini hanyalah bersifat tekstualisskripturalis. Karena konsep shalat yang dilakukannya dipandang sebagai faktasitas objektif yang telah hidup dan bersemi di dalam masyarakat.
Selanjutnya melalui proses internalisasi, mereka akan kembali menyerap makna shalat yang ada dalam realitas obyektif, dan akan membawa kembali ke dalam diri individu masing-masing, dan tidak tertutup kemungkinan mereka akan menemukan makna shalat yang baru dari realita objektif lain yang mereka temukan.

\section{Daftar Kepustakaan}

\section{Buku.}

Ahmadi. Abu. Mutiara Isra' Mi'raj. Jakarta: Bumi Aksara. 2007.

Al-Asqalaniy, Ahmad ibn 'Ali Ibn Hajar. Fath al- Baari Syarah Shohih al-Bukhāri, Amirudin(terj.) Jakarta: Pustaka Azzam. 2009.

Subul al Salām syarh Bulugh al Marrām min Jami Adillat Ahkām. Semarang: Toha Putra. t.t.

Al-Bahwati,Mansur bin Yunus.alRaudhu al-Murabba`. Riyadh: Maktabah al-Riyadh alHaditsah. 1390 H.

Ali, Jawwad. Tarikh ash-Shalat fi alIslam. Irwan Masduki (terj.). Tanggerang: Lentera Hati. 2013.

Al-Mubarakfuri, Syeikh Shafiyurrahman. ar-Rahiq alMakhtūm. Muhammad Misbah. (terj.) Surakarta: Shahih. 2012.

Al-Qurthubi, Abi Abdullah Muhammad Ibn Ahmad al Ansariy. al-Jami`li Ahkam alQur'ān. Beirut: Dar al-Kutub al-Ilmiyyah. 2005. 
Al-Shafi iy, Ali Ibnu Burhanuddin alHalibiy. Min Insan al- 'Uyun $f i$ Sirat al-Amin al-Ma'mun alMa'ruf bi Sirah al-Halibiyah. Mesir: Muhammad Ali Shabih. 1935.

Al-Shawkan̄̄, Muhammad Ibnu Ali Ibnu Muhammad. Nayl alAwtār Syarh Muntaqa alAkhbār bihi Ahadith Sayyid al$A k h b \overline{a r}$. Kairo: Matbah Mustafa al-Babiy al-Halabi. t.t.

Amal, Taufik Adnan. Rekonstruksi Sejarah al-Qur'ān. Jakarta: Divisi Muslim Demokratis. 2011.

Al-Nawawi,Abu Zakaria Yahya bin Syaraf.Syarh an-Nawawi 'Ala Muslim. Beirut: Dar Ihya atTurats al-'Arabi. 1392 H.

Al-Suyuthi, Imam Jamaluddin. al-Itqān fi 'Ulūmi al-Qur'ān. Beirut: Darul Kutub al-Ilmiah. 2004. al-Durr al-Mantsur fi Tafsir alMa'tsur. Kairo: Nasyr Kitabkhane Ayatullah Mar’asyi. $1402 \mathrm{H}$.

Lubabun Nuquul fii Asbābin Nuzūl. Kairo: Darul Taqwa. t.t.

Al-Syinqithi, Muhammad Al-Amin bin Muhammad Al-Mukhtar. Tafsir Adhwa ul Bayān fi Idhah alQur'ān bi Qur 'ān. Mesir-Kairo: Darul Kutub al-Ilmiyyah. 1972

Athaillah. Sejarah al-Qur'ān (Verifikasi tentang Otensitas alQur'ān). Yogyakarta: Pustaka Pelajar. 2010.

Al-Thabarī, Abi Ja'far Muhammad IbnuJarīr.Jami` al-Bayān anTa 'wil ay al-Qur 'ān. Kairo: Dar al-Hadith. 2010.
Berger,Peter L. LangitSuci (Agama SebagaiRealitasSosial). Hartono (terj.) .Jakarta: LP3ES. 1991.

The Study of Releigion. Linda Woodhead with Paul Heelas and David Martin, (ed.). London: Routledge. 2001.

Bungin, H.M Burhan. Penelitian Kualitatif. Jakarta: Kencana. 2012.

KonstruksiSosial Media Massa: KekuatanPengaruh Media Massa, IklanTelevisidan Keputusan KonsumensertaKritikTerhadap Peter L. Berger dan Thomas Luckmann.Jakarta: Kencana. 2008.

Cohen,Abraham.Everyman's Talmud.New York: Schocken. 1995.

Goiten, S.D. Studies In Islamic History And Institutions. Leiden: E.J. Brill: 1968.

Hadi, Ibnu Sayyid al-Nas, Ibnu Abdul. Min Uyūn al-Atsār fi Fanun alMaghaziy wa al-Shamail wa alSiyār. Beirut: Dar al-Ma rifah t.t.

Haekal, Muhammad Husain. Sejarah Hidup Muhammad. Jakarta: Penerbit Litera Antar Nusa, 2013.

Hisyam, Ibnu. al-Sirāh al-Nabawiyyah. Beirut: Dar al-Kutub al'Ilmiyyah. 2009.

Ishaq, Abu al-Faraj Muhammad Ibnu Ishaq Ibnu Muhammad Ibnu. al-Fihrist. Bayard (terj.) Columbia University: New York \& London. 1970. 
Karīm, Khalil Abdul. al-Judzūr alTarikhiyyah li al-Syariah alIslamiyah. Kairo: Dar Misra alMahrusah 2004.

Katsir, Al-Hafizh 'Imaduddin Abu alFida' Ismail Ibnu.Tafsir alQur'an al-Azhim.Beirut: Maktabah al-Nur al-'Ilmiyyah. 1992.

Al-Bidayah Wa al-Nihayah. Muhammad Ghazy Baydun. (ed.). Beirut: Dar al-Ma'rifah. 2007.

Lings,Martin.Muhammad: His Life Based on the Earliest Source. United Kingdom-Cambridge: The Islamic Texts Society 1991.

Lukhmann, Peter L. Berger \& Thomas. Tafsir Sosial atas Kenyataan. Hasan Basri(terj.)Jakarta:LP3ES.1990.

Ma rifat, M. Hadi. Sejarah al-Qur 'ān. Thoha Musawa (terj.) Jakarta: Al-Huda 2007.

Pals,Daniel L.TujuhTeori Agama Paling Komprehensif. InyiakRidwanMuzir(terj.) Yogyakarta: IRCiSoD. 2012.

Syam, Nur. Islam Pesisir. Yogyakarta: Lkis Pelangi Aksara. 2005.

Zukhaili, Wahbat bin Mustafa. alTafsir al-Munir fi al-'Aqidat wa al-Syari'ah wa al-Manhaj, Cet. Ke-2. Beirūt: Dar-al-Fikr alMa`ashīr $1418 \mathrm{H}$.

\section{Hadis}

Bukhāri, Imam al-Hafiz Abu 'Abdillah Muhammad Ismâîl Bukhari. Shahîh al-Bukhâri. Amman:
Bayt al-Afkar al-Dawliyyah, 1998 M.

\section{Kamus}

Manzhur. Lisan al'Arab. Beirut: Dar al Kutub al' Ilmiyyah. 2009.

Al-Asfahāni, Al-Raghib. al-Mufradat fi Gharib al-Qur 'àn. Mesir: alMaimanah. $1424 \mathrm{H}$.

Baqi,Muhammad Fu'ad Abdul. alMu jam al-Mufahras li alfāzhi al-Qur`ān al-Karìm. Kairo: Dar al-Hadits. 1994.

Hastings, James. Dictionary of the Bible.New York: Baker Books 1994.

\section{Rujukan Web}

Wikipedia. "Peter L. Berger" https://id.wikipedia.org/wiki/Peter_L. Berger, diakses pada tanggal 20

Februari 2017.

Wikepedia."ThomasLuckmann". https://en.wikipedia.org/wiki/Thomas Luckmann, diaksespadatanggal 20 Februari 2017 
88 Jurnal Ulunnuha Vol. 8 No.1/Juni 2019 